\title{
Two New 5-Hydroxy-2-pyrone Derivatives Isolated from a Marine-derived Fungus Aspergillus flavus
}

\author{
Aiqun Lin*, Xiaoming Lu*, Yuchun Fang, Tianjiao Zhu, Qianqun Gu, Weiming Zhu
}

Received: January 17, 2008 / Accepted: March 31, 2008

(C) Japan Antibiotics Research Association

\begin{abstract}
Two new compounds, 4-(hydroxymethyl)-5hydroxy-2H-pyran-2-one (1) and (5-hydroxy-2-oxo- $2 H$ pyran-4-yl) methyl acetate (2), have been isolated from a marine-derived fungus Aspergillus flavus. Their structures were determined by spectroscopic data. Compound 1 induced the production of cAMP on GPR12 transfected CHO and HEK293 cells in a dose-dependent manner, which indicated 1 might be a possible ligand for GPR12.
\end{abstract}

Keywords marine-derived fungus, Aspergillus flavus, 5hydroxy-2-pyrone, cAMP, GPR12

\section{Introduction}

2-Pyrone is a six-membered cyclic unsaturated ester, which is highly abundant in bacteria, microbial, plant, insect and animal systems and takes part in many different types of biological processes such as defence against other organisms, as key biosynthetic intermediates, and as metabolites [1]. A wide range of bioactivities such as plant growth-regulating [2, 3], antitumour [4, 5], antimicrobial and antifungal activities $[6,7]$ have demonstrated the medicinal importance of 2-pyrones. In our search for new bioactive compounds from the marine-derived fungus Aspergillus flavus c-f-3 separated from a marine algae sample collected in Putian Pinghai, China, two new 5hydroxy-2-pyrone derivatives $(\mathbf{1}, \mathbf{2})$ were isolated. The biological activities of $\mathbf{1}$ and $\mathbf{2}$ were tested using cAMP assay in GPR12 transfected CHO and HEK293 cells. In this paper we described the isolation and structure elucidation of $\mathbf{1}$ and $\mathbf{2}$ (Fig. 1) as well as their bioactivities.

\section{Materials and Methods}

\section{Microorganism}

The Aspergillus flavus c-f-3 was separated from a marine algae Enteromorpha tubulosa, collected at Putian Pinghai, China, in August, 2005, using dilution-plate method [8] on PDA medium [9]. It was identified according to its morphological characteristic by Prof. Hong Kui (the Chinese Academy of Tropical Agricultural Sciences, Hainan, China). Working stocks were prepared on Potato Dextrose agar slants stored at $4^{\circ} \mathrm{C}$.<smiles>O=c1cc([14CH2]O)c(O)co1</smiles>

1<smiles>CC(=O)OCc1[14cH]c(=O)occ1O</smiles>

2
Fig. 1 Structures of compounds 4-(hydroxymethyl)-5hydroxy-2H-pyran-2-one (1) and (5-hydroxy-2-oxo-2H-pyran4-yl) methyl acetate (2).
Q. Gu, W. Zhu (Corresponding author), A. Lin, Y. Fang, T. Zhu: Key Laboratory of Marine Drugs, Chinese Ministry of Education, School of Medicine and Pharmacy, Ocean University of China, Qingdao 266003, P.R. China,

E-mail: guqianq@ouc.edu.cn,weimingzhu@ouc.edu.cn
X. Lu: Key Laboratory of Brain Functional Genomics, MOE \& STCSM, Shanghai Institute of Brain Functional Genomics, East China Normal University, Shanghai 200062, China

* Authors make equal contribution to this paper. 


\section{Fermentation}

A small spoon of spores growing on potato dextrose agar slant was inoculated into a $500 \mathrm{ml}$ conical flask containing $150 \mathrm{ml}$ of the liquid medium composed of glucose (1.0\%), maltose $(2.0 \%)$, and yeast extract $(0.3 \%)$, mannitol (2.0\%), monosodium glutamate (1.0\%), $\mathrm{KH}_{2} \mathrm{PO}_{4}(0.05 \%)$, $\mathrm{MgSO}_{4} \cdot 7 \mathrm{H}_{2} \mathrm{O}(0.03 \%)$, corn plasm $(0.1 \%)$ and artificial seawater after adjusting its $\mathrm{pH}$ to 6.5 , and cultured at $28^{\circ} \mathrm{C}$ for three days on a rotary shaker at $165 \mathrm{rpm}$. Then $10 \mathrm{ml}$ of the resultant seed culture was inoculated into $500 \mathrm{ml}$ conical flask each containing $150 \mathrm{ml}$ of the above culture medium and incubated at $28^{\circ} \mathrm{C}$ for seven days on a rotary shaker at $165 \mathrm{rpm}$.

\section{Extraction and Isolation}

The culture whole broth (30 liters) was filtered through cheesecloth to separate into supernatant and mycelia. The supernatant (26 liters) was extracted with ethyl acetate ( $3 \times 30$ liters), while the mycelia were extracted with $70 \%$ acetone-aqueous $(3 \times 4$ liters). The acetone solution was concentrated under reduced pressure to afford an aqueous solution, which was extracted with ethyl acetate $(3 \times 3$ liters). Both ethyl acetate solutions were combined and concentrated under reduced pressure to give a crude extract (30.2 g).

The crude extract was separated into eight fractions on a silica gel (300 400 mesh) column using a step gradient elution of $\mathrm{CHCl}_{3}-\mathrm{MeOH}(100 \%-50 \%)$. The sixth fraction of $5.0 \% \mathrm{MeOH}$, was chromatographed on a Sephadex LH20 column with $50 \% \mathrm{CHCl}_{3} / \mathrm{MeOH}$. Every $100 \mathrm{ml}$ eluent were collected and combined into four fractions based on TLC properties. The third fraction $(1.7 \mathrm{~g})$ was rechromatographed on a column of reverse silica gel (RP18, 40 60 $\mu \mathrm{m}$, Merck) with $\mathrm{H}_{2} \mathrm{O} / \mathrm{MeOH}$ gradient system and the $100 \% \mathrm{H}_{2} \mathrm{O}$ eluate, containing the mixture of $\mathbf{1}$ and $\mathbf{2}$, which showed red color when sprayed chromatoplate with $\mathrm{FeCl}_{3}$ alcohol solution, was further purified by semipreparative HPLC using an ODS column [YMC-pack ODS (A) $, 10 \times 250 \mathrm{~mm}, 5 \mu \mathrm{m}, 4 \mathrm{ml} /$ minute, $\left.40 \% \mathrm{MeOH} / \mathrm{H}_{2} \mathrm{O}\right]$ to give $\mathbf{1}(1.1 \mathrm{~g})$ and $2(9.7 \mathrm{mg})$.

\section{Biological Assays}

Plasmid Construction

Full-length cDNA of human GPR12 was amplified by PCR from pCMV6-XL4-GPR12 vector (a gift from Dr. Cecilia Jiang, Genomics Institute of Novartis Research Foundation, San Diego, USA) using the gene-specific primers 5'-GGGGTACCATGAATGAAGACCTGAAGGTC-3' and 5'-CCGCTCGAGCTACACATCACTGGGCGAG-3' for expression. The GPR12 PCR product was transferred into the KpnI-XhoI sites of the vector Myc-
pcDNA3.1 (+) (also a gift from Dr. Cecilia Jiang) and sequenced to ensure correct insertion and sequence.

\section{Cell Culture, Transfection and Subclone Selection}

Chinese Hamster Ovary cells (CHO-K1, preserved in our lab) were cultured in RPMI Medium 1640 (with L-glutamine, without sodium bicarbonate, GIBCO) supplemented with $10 \%$ fetal bovine serum (FBS, PAA), penicillin/streptomycin $(10,000 \mathrm{IU} / \mathrm{ml}-10,000 \mathrm{ug} / \mathrm{ml}$, PAA) and $400 \mathrm{ug} / \mathrm{ml} \mathrm{G} 418$ (Calbiochem), pH 7.2, in a humidified $5.0 \% \mathrm{CO}_{2}$ incubator. Transfections were performed by using Lipofectamine ${ }^{\mathrm{TM}} 2000$ (invitrogen) as directed by the manufacturer for a 12-well plate, $2.0 \mu \mathrm{g}$ of pcDNA3.1-myc -GPR12 vector and $3.0 \mu \mathrm{l}$ lipofectamine ${ }^{\mathrm{TM}} 2000$ reagent were used. 48 hours after the transfection, $750 \mu \mathrm{g} / \mathrm{ml} \mathrm{G} 418$ (Calbiochem) was added, and stable single clones were obtained by macrography selection using gradient dilution in 96-well plate. These clones were expanded in growth medium with G418 $(500 \mu \mathrm{g} / \mathrm{ml})$.

Cell Based cAMP Assay

PcDNA3.1-GPR12-transfected CHO (GPR12-CHO) subclone and PcDNA3.1-transfected $\mathrm{CHO}$ (vector-CHO) were cultured in 384-well plates for 24 hours. Both cells were treated with drugs for 30 minutes at room temperature and measured by Htrf cAMP dynamic bulk kit which is intended for direct quantitative determination of cyclic AMP. Fluorescence was detected at 620 and $665 \mathrm{~nm}$ using Analyst HT (Molecular Devices).

Data Evaluation and Statistic Analysis

The sigmaplot (Systat Software Inc, USA) was used for curve fitting; the $t$ test was applied to evaluate statistical significance.

\section{Results and Discussion}

\section{Physico-chemical Properties}

Compound 1: colorless crystal $(\mathrm{MeOH}) ; \mathrm{mp} 138 \sim 140^{\circ} \mathrm{C}$; HRESI-MS $m / z 141.0183$ for $[\mathrm{M}-\mathrm{H}]^{-}$(calcd. for $\mathrm{C}_{6} \mathrm{H}_{5} \mathrm{O}_{4}$, 141.0188); IR (KBr) $v_{\max } 3258,3176,1615,1460$, $1283 \mathrm{~cm}^{-1}$; UV (MeOH): $\lambda_{\max } \mathrm{nm}(\log \varepsilon) 213$ (4.75), 273 (3.91); ${ }^{1} \mathrm{H}$ - and ${ }^{13} \mathrm{C}-\mathrm{NMR}$ (DMSO- $d_{6}, 600 \mathrm{MHz}$ and $150 \mathrm{MHz})$ see Table 1.

Compound 2: amber amorphous solid; $\mathrm{mp} 118 \sim 120^{\circ} \mathrm{C}$; HRESI-MS $\mathrm{m} / \mathrm{z} 207.0264$ for $[\mathrm{M}+\mathrm{Na}]^{+}$(calcd. for $\left.\mathrm{C}_{8} \mathrm{H}_{8} \mathrm{O}_{5} \mathrm{Na}, 207.0269\right) ; \mathrm{UV}(\mathrm{MeOH}): \lambda_{\max } \mathrm{nm}(\log \varepsilon) 217$ (4.63), 269 (4.35); ${ }^{1} \mathrm{H}$ - and ${ }^{13} \mathrm{C}-\mathrm{NMR}$ (DMSO- $d_{6}, 600 \mathrm{MHz}$ and $150 \mathrm{MHz})$ see Table 1. 
Table $1{ }^{1} \mathrm{H}$ - and ${ }^{13} \mathrm{C}-\mathrm{NMR}, \mathrm{HMBC}$ data for 4-(hydroxymethyl)-5-hydroxy-2 $\mathrm{H}$-pyran-2-one (1) and (5-hydroxy-2-oxo-2 $\mathrm{H}$-pyran4-yl) methyl acetate (2) (DMSO- $d_{6}, 600$ and $150 \mathrm{MHz}, \mathrm{TMS}, \delta$ in ppm)

\begin{tabular}{|c|c|c|c|c|c|c|}
\hline \multirow{2}{*}{ No. } & \multicolumn{3}{|c|}{1} & \multicolumn{3}{|c|}{2} \\
\hline & $\delta_{\mathrm{H}}(\mathrm{J}$ in $\mathrm{Hz})$ & $\delta_{\mathrm{C}}$ & $\mathrm{HMBC}$ & $\delta_{\mathrm{H}}(\mathrm{J}$ in $\mathrm{Hz})$ & $\delta_{\mathrm{C}}$ & $\mathrm{HMBC}$ \\
\hline 2 & & $173.9 \mathrm{~s}$ & & & $173.7 \mathrm{~s}$ & \\
\hline 3 & $6.34(1 \mathrm{H}, \mathrm{s})$ & $109.8 d$ & $2,4,5,7$ & $6.47(1 \mathrm{H}, \mathrm{s})$ & $112.5 d$ & $2,4,5,7$ \\
\hline 4 & & $145.7 \mathrm{~s}$ & & & $146.0 \mathrm{~s}$ & \\
\hline 5 & & $168.1 \mathrm{~s}$ & & & $161.6 \mathrm{~s}$ & \\
\hline 6 & $8.03(1 \mathrm{H}, \mathrm{s})$ & $139.2 d$ & $2,4,5$ & $8.09(1 \mathrm{H}, \mathrm{s})$ & $139.9 d$ & $2,4,5$ \\
\hline 7 & $4.29(2 \mathrm{H}, \mathrm{s})$ & $59.5 \mathrm{t}$ & 3,5 & $4.93(2 \mathrm{H}, \mathrm{s})$ & $61.3 t$ & $3,5,9$ \\
\hline 9 & & & & & $169.8 \mathrm{~s}$ & \\
\hline 10 & & & & $2.11(3 \mathrm{H}, \mathrm{s})$ & $20.4 q$ & 9 \\
\hline $5-\mathrm{OH}$ & $9.07(1 \mathrm{H}, \mathrm{s})$ & & 6 & $9.26(1 \mathrm{H}, \mathrm{s})$ & & \\
\hline $7-\mathrm{OH}$ & $5.67(1 \mathrm{H}, \mathrm{s})$ & & & & & \\
\hline
\end{tabular}

\section{Structure Determination}

Compound 1 was obtained as a colorless crystal. Highresolution ESI-MS revealed a molecular ion peak at $\mathrm{m} / \mathrm{z}$ 141.0183 for $[\mathrm{M}-\mathrm{H}]^{-}$(calcd. 141.0188) corresponding with the molecular formula $\mathrm{C}_{6} \mathrm{H}_{6} \mathrm{O}_{4}$ and four degrees of unsaturation. The IR spectrum absorptions at 1615 and $3176 \mathrm{~cm}^{-1}$ indicated the presence of a carbonyl group and a hydroxyl functionality. The ${ }^{13} \mathrm{C}$ - and DEPT NMR spectra revealed the presence of one oxygenated aliphatic methylene carbon $\left(\delta_{\mathrm{C}} 59.5\right)$, two olefinic methine carbons $\left(\delta_{\mathrm{C}} 109.8,139.2\right)$, one enolic carbon $\left(\delta_{\mathrm{C}} 168.1\right)$, one quaternary olefinic carbon $\left(\delta_{\mathrm{C}} 145.7\right)$, and a carbonyl carbon $\left(\delta_{\mathrm{C}}\right.$ 173.9). The above data indicated that $\mathbf{1}$ possessed a hydroxy-substituted 2-pyrone ring [10]. ${ }^{1} \mathrm{H}-$ and ${ }^{13} \mathrm{C}$-NMR data of $\mathbf{1}$ were similar to those of 5-hydroxy$\alpha$-pyrone (except for the increase of one hydroxymethyl) [11]. The presence of the 4-hydroxymethyl of $\mathbf{1}$ was indicated by the ${ }^{1} \mathrm{H}-\mathrm{NMR}$ [4.29 $\left.(2 \mathrm{H}, \mathrm{s}), 5.67(1 \mathrm{H}, \mathrm{s})\right]$. Additionally, HMBC correlations (Fig. 2) from $\delta_{\mathrm{H}} 6.34$ $(1 \mathrm{H}, \mathrm{s}, \mathrm{H}-3)$ to $\mathrm{C}-2, \mathrm{C}-4, \mathrm{C}-5$ and C-7, from $\delta_{\mathrm{H}} 8.03(1 \mathrm{H}, \mathrm{s}$, $\mathrm{H}-6)$ to $\mathrm{C}-2, \mathrm{C}-4$ and $\mathrm{C}-5$, from $\delta_{\mathrm{H}} 4.29(2 \mathrm{H}, \mathrm{s}, \mathrm{H}-7)$ to C3 , C-5 established the structure of $\mathbf{1}$ as 4-(hydroxymethyl)5-hydroxy-2H-pyran-2-one.

Compound 2 was obtained as an amber amorphous solid. High-resolution ESI-MS supported the molecular formula $\mathrm{C}_{8} \mathrm{H}_{8} \mathrm{O}_{5}\left(\mathrm{~m} / \mathrm{z} 207.0264\right.$ for $[\mathrm{M}+\mathrm{Na}]^{+}$, calcd. 207.0269) with five degrees of unsaturation. Comparison of the NMR spectra of $\mathbf{1}$ and $\mathbf{2}$ indicated their close similarities. The differences of them were the replacement of 7-OH $(\delta 5.67)$ in 1 by an acetyl group $\left(\delta_{\mathrm{H}} 2.11, \delta_{\mathrm{C}} 169.8,20.4\right)$ in $\mathbf{2}$. The HMBC correlations (Fig. 2) from $\delta_{\mathrm{H}} 2.11(3 \mathrm{H}, \mathrm{s}, \mathrm{H}-10)$ to C-9 $(\delta 169.8, \mathrm{C})$, from $\delta_{\mathrm{H}} 4.93(2 \mathrm{H}, \mathrm{s}, \mathrm{H}-7)$ to $\mathrm{C}-3, \mathrm{C}-5(\delta$

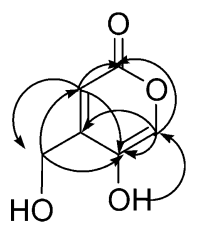

1

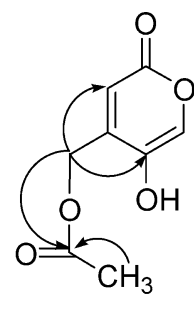

2
Fig. 2 Key HMBC correlations for $\mathbf{1}$ and $\mathbf{2}$.

161.6), C-9 indicated an upfield shift of C-5 in 2 at $161.6 \mathrm{ppm}$ compared to $168.1 \mathrm{ppm}$ in $\mathbf{1}$ and the new acetyl carbonyl in 2 at $169.8 \mathrm{ppm}$. These data established the structure of $\mathbf{2}$ as (5-hydroxy-2-oxo-2H-pyran-4-yl) methyl acetate.

\section{Biological Activities}

Compounds 1 and $\mathbf{2}$ were tested by cAMP assay [12] on GPR12-transfected cells and their vector-transfected controls, including Chinese hamster ovary cells (CHO) and human embryonic kidney cells (HEK293). Our results (Fig. 3) showed 1 could promote a small but significant cAMP increase in a dose-dependent manner on both GPR12-CHO cells and GPR12-HEK293 cells, while no significant difference on their vector controls, however, 2 didn't show any activity at the concentration of $100 \mu \mathrm{M}$.

The cytotoxicities of $\mathbf{1}$ and $\mathbf{2}$ were evaluated on HL-60 and A-549 cell lines by the MTT method [13], but neither of them registered any cytotoxicity at the concentration of $100 \mu \mathrm{M}$. 

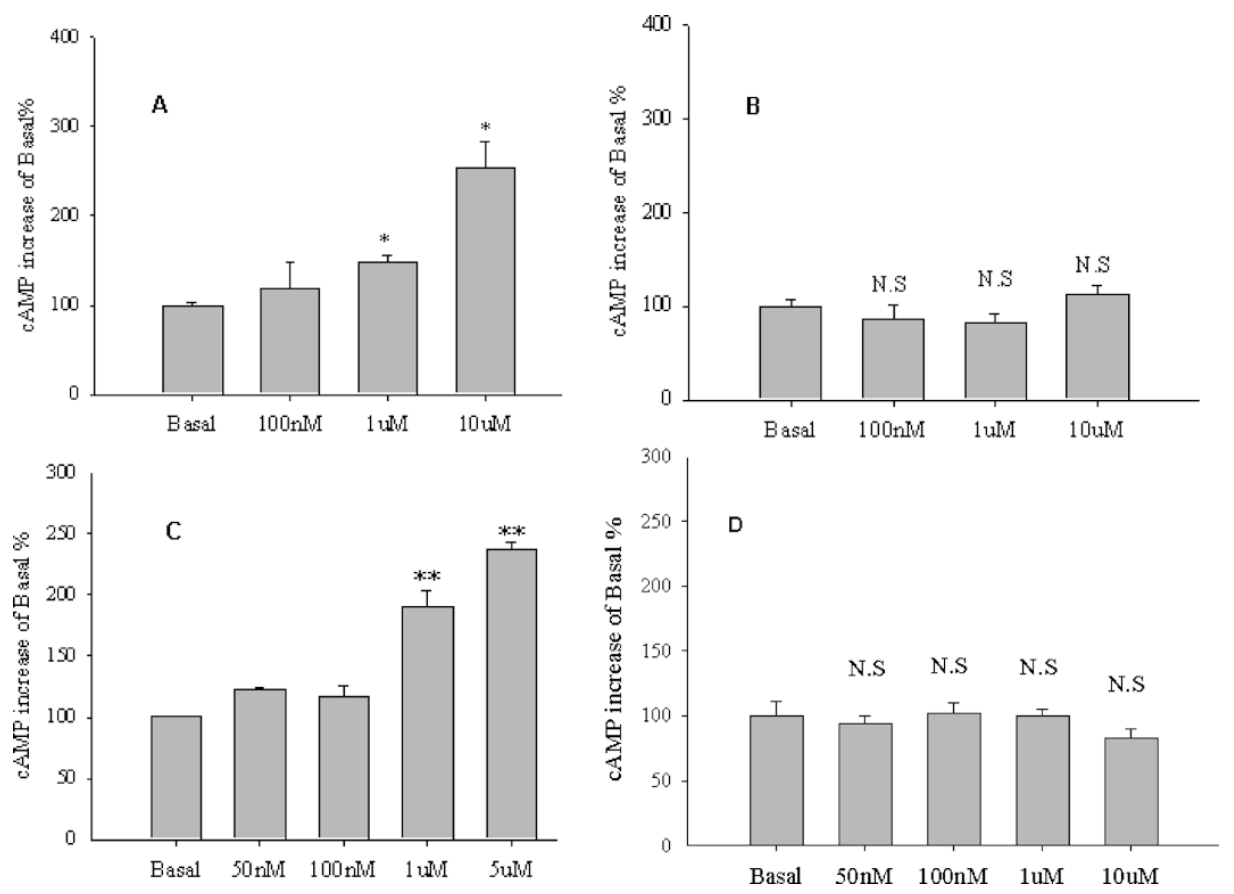

Fig. 3 Characterization of compound 1 using CAMP assay on GPR12 transfected cells, including CHO and HEK293.

1 promoted cAMP increase on GRR12-CHO cells (A); NS on vector-CHO cells (B); on GPR12-HEK293 cells (C); on vector-HEK293 cells (D); The Sigmaplot (Systat Software Inc, USA) was used for curve fitting; the $t$ test was applied to evaluate statistical significance. Statistical significant was indicated: ${ }^{*} \mathrm{P}<0.05,{ }^{*} \mathrm{P}<0.005$, N.S refers to no significant difference.

\section{Discussion}

G protein-coupled receptors (GPCRs) have been a productive and useful target for the pharmaceutical industry and recently some of these receptors seem to be potent targets of an estimated $45 \%$ of marketed drugs [14]. Therefore, the uncharacterized orphan GPCRs can be expected to represent possible novel therapeutic targets in the future [15]. The GPR12 homologue was initially cloned from rat pituitary gland [16] and human GPR12 was cloned in 1995 [17]. The latest studies show that GPR12 together with GPR3 and GPR6 are highly expressed in the central nervous system and their expression in neurons results in constitutive stimulation of cAMP production, stimulates neurite outgrowth, and counteracts myelin inhibition, indicating that GPR12 can be significant molecular target for treating a variety of neurological disorders, including brain and spinal cord injuries, stroke, and neurodegenerative disorders [18].

Early in 2002, Uhlenbrock et al. reported sphingosine1-phosphate (S1p) was possibly a ligand for GPR12 [12]. And several months later, Ignatov et al. reported sphingosyl-phosphorylcholine (SPC) was a much higheraffinity ligand than S1p for GPR12 [19]. We for the first time reported the 2-pyrone derivative might be a possible ligand for GPR12. The much more inductive effect of 1 than 2 indicates that 7-OH moiety plays an important role in the structure-activity relationship. Further pharmacological analysis should be performed to determine whether the compound could be specific agonist for GPR12.

Acknowledgement This work was financially supported by the Shandong Province Natural Science Fund (No. Z2006C13) and Chinese National Programs for High Technology Research and Development (No. 2007AA09Z447). The Aspergillus flavus was identified by Professor Hong Kui at the Chinese Academy of Tropical Agricultural Sciences, Hainan, China.

\section{References}

1. McGlacken GP, Fairlamb IJS. 2-Pyrone natural products and mimetics: isolation, characterisation and biological activity. Nat Prod Rep 22: 369-385 (2005)

2. Kobayashi S, Tsuchiya K, Kurokawa T, Nakagawa T, Shimada N, Iitaka Y. Pironetin, a novel plant growth regulator produced by Streptomyces sp. NK10958. II. Structural elucidation. J Antibiot 47: 703-707 (1994)

3. Tsuchiya K, Kobayashi S, Nishikiori T, Nakagawa T, Tatsuta 
K. Epopromycins, novel cell wall synthesis inhibitors of plant protoplast produced by Streptomyces sp. NK04000. J Antibiot 50: 261-263 (1997)

4. Suzuki K, Kuwahara A, Yoshida H, Fujita S, Nishikiori T, Nishikiori T. NF00659A1, A2, A3, B1 and B2, novel antitumor antibiotics produced by Aspergillus sp. NF 00659. I. Taxonomy, fermentation, isolation and biological activities. J Antibiot 50: 314-317 (1997)

5. Kondoh M, Usui T, Kobayashi S, Tsuchiya K, Nishikawa K, Nishikiori T, Mayumi T, Osada H. Cell cycle arrest and antitumor activity of pironetin and its derivatives. Cancer Lett 126: 29-32 (1998)

6. Barrero AF, Oltra JE, Herrador MM, Cabrera E, Sanchez JF, Quílez JF, Rojas F, Reyes JF. Gibepyrones: $\alpha$-pyrones from Gibberella fujikuroi. Tetrahedron 49: 141-150 (1993)

7. Parker SR, Culter HG, Jacyno JM, Hillf RA. Biological activity of 6-pentyl-2H-pyran-2-one and its analogs. J Agric Food Chem 45: 2774-2776 (1997)

8. Christensen CM. Influence of small differences in moisture content upon the invasion of hard red winter wheat by Aspergillus restrictus and A. repens. Cereal Chem 40: 385-390 (1963)

9. Nielsen P, Sørensen J. Multi-target and medium-independent fungal antagonism by hydrolytic enzymes in Paenibacillus polymyxa and Bacillus pumilus strains from barley rhizosphere. FEMS Microbiol Ecol 22: 183-192 (1997)

10. Hirota A, Nemoto A, Tsuchiya Y, Hojo H, Abe N. Isolation of a 2-pyrone compound as an antioxidant from a fungus and its new reaction product with 1,1-diphenyl-2picrylhydrazyl radical. Biosci Biotechnol Biochem 63: 418-420 (1999)

11. Yasuyuki H. Isolation of 5-hydroxy- $\alpha$-pyrone and its $\beta$-Dglucoside from Erigeron and their use as aging inhibitors for plants and glycosidase inhibitors. JP 04198177, July 17 (1992)

12. Uhlenbrock K, Gassenhuber H, Kostenis E. Sphingosine 1phosphate is a ligand of the human GPR3, GPR6 and GPR12 family of constitutively active G protein-coupled receptors. Cell Signal 14: 941-953 (2002)

13. Mosmann T. Rapid colorimetric assay for cellular growth and survival: application to proliferation and cytotoxicity assays. J Immunol Methods 65: 55-63 (1983)

14. Drews J. Drug discovery: a historical perspective. Science 287: 1960-1964 (2000)

15. Bjursell M, Gerdin AK, Jōnsson M, Surve VV, Svensson L, Huang XF, Tōrnell J, Bohlooly-YM. G protein-coupled receptor 12 deficiency results in dyslipidemia and obesity in mice. Biochem Biophys Res Commun 348: 359-366 (2006)

16. Eidne KA, Zabavnik J, Peters T, Yoshida S, Anderson L, Taylor PL. Cloning, sequencing and tissue distribution of a candidate $G$ protein-coupled receptor from rat pituitary gland. FEBS 292: 243-248 (1991)

17. Song ZH, Modi W, Bommer TI. Molecular cloning and chromosomal localization of human genes encoding three closely related $\mathrm{G}$ protein-coupled receptors. Genomics 28: 347-349 (1995)

18. Tanaka S, Ishii K, Kasai K, Yoon SO, Saeki Y. Neural expression of $\mathrm{G}$ protein-coupled receptors GPR3, GPR6, and GPR12 up-regulates cyclic AMP levels and promotes neurite outgrowth. J Biol Chem 282: 10506-10515 (2007)

19. Ignatov A, Lintzel J, Hermans-Borgmeyer I, Kreienkamp HJ, Joost P, Thomsen S, Methner A, Schaller HC. Role of the G-protein-coupled receptor GPR12 as high-affinity receptor for sphingosylphosphorylcholine and its expression and function in brain development. J Neurosci 23: 907-914 (2003) 